\title{
INTERCULTURAL DIMENSIONS OF EDUCATION
}

\begin{abstract}
The paper discusses the development and the conceptualization of intercultural education, particularly within the Central-European pedagogical tradition. The author defends the thesis that intercultural education needs to be developed within the tradition of critical pedagogy, and linked to the main topicalities of pedagogical research, namely that of general theory of education and didactics. Intercultural education should therefore address the power inequalities of the education system itself, which primarily involves implementing a multi-perspective and anti-bias curriculum and creating a democratic, pluralistic, inclusive school ethos. Moreover, intercultural education is not defined as a specific pedagogical discipline, but as a pedagogical principle which guides the processes of planning, implementing, and evaluating education at the systemic, curricular, school, and classroom levels to enable recognition and empowerment of all minority groups. The paper concludes with a brief discussion on pedagogical measures to support intercultural education, including the role of the teachers.
\end{abstract}

Keywords: intercultural education, multicultural education, teacher education, critical pedagogy.

\section{Introduction}

Discussions on intercultural or multicultural issues in education have been taking place in educational theory and practice since at least the 1960s. After first focusing on ethnic revitalization movements in the U.S.A., Canada, and Australia, they were soon applied to the migration processes in Europe. After World War II Europe experienced many waves of economic migration. On one side migrants from colonial nations began arriving, and on the other were the migrants from Southern and Eastern Europe moving to Western and Northern Europe; all were looking for better lives and working conditions (Banks, 2009).

The development of intercultural education is abundantly documented (Banks, 2009; Cushner, 1998; Diehm \& Radtke, 1999; Ermenc, 2015; Grant \& Portera, 2011; McCarthy, 1995; Sleeter \& Grant, 1987; 2006; Young, 1995), revealing a multitude of theoretical

1 E-mail: klara.skubic-ermenc@ff.uni-lj.si 
views and practical models. To simplify only a little, we can conclude that there are two primary global approaches to the issues of a multicultural student body. The first approach has been often called the assimilationist approach, and the second integrative or multi- or intercultural approach (Banks, 2009; Cushner, 1998; Diehm \& Radtke, 1999; Troyna, 1992). In the U.S.A. the multicultural approach has soon developed, but it has never been monolithic. On the contrary, by 1987 Sleeter and Grant described five prevailing models of multicultural education (updated in 2006). They distinguish the following models: (1) teaching the exceptional and the culturally different, the main aim which is to prepare students to function in American society. The model did not leave the assimilationist perspective completely behind, but was inspirational for later models; (2) human relations, which strives to build better relationships among people of different cultural backgrounds, so as to reduce hostility and prejudice. It does not address the issue of power relations; (3) single-group study, which advocates comprehensive study of marginalized groups' history, experiences with oppression, and resistance. Its main problems are that it leaves mainstream curriculum untouched and can promote separatism; (4) multicultural education, based on promoting values such as cultural diversity, respect for difference, human rights and social justice, and equal opportunities. The model is designed to include the entire student population, but has been criticized for not paying enough attention to structural inequalities; and (5) multicultural and social reconstructionist education, which Sleeter and Grant prefer, is grounded in the critique of modern culture and its unjust structure. In their view, education should empower students from different social groups experiencing discrimination to challenge the unjust status quo.

Germany was one of the first nations in Western Europe that reacted to the mass immigration. Already by the 1960s, the field of social pedagogy (Sozial Pedägogik) had established Ausländer Pedägogik ("foreigner pedagogy", see Diehm \& Radtke, 1999; Faas, 2008). Foreigner pedagogy was based on assimilationist notions, and was focused on the migrant students who were perceived as handicapped by their poor command of the German language. Foreign pedagogy thus emphasized the teaching of the German language and other compensatory strategies targeted at various learning gaps. In the 1980s and 1990s, foreigner pedagogy underwent serious critique, and has since been gradually replaced by intercultural pedagogy (at least in theory, less so in practice). Intercultural pedagogy has brought about a change of focus: it addresses all students and defends the idea that citizens need to learn to live in a culturally diverse society. Moreover, minority identities have to be recognized and every student needs to be supported to fulfil her potential and aspirations. Critical pedagogues have also argued that intercultural pedagogy needs to address the power inequalities of the education system itself, which primarily involves implementing a multi-perspective and anti-bias curriculum and creating a democratic, pluralistic, inclusive school ethos. Similar stances have been taken by some English authors, who have developed anti-racist education (Faas, 2008; Troyna, 1992).

(American) critical multiculturalism, (English) anti-racist education, and (German) critical intercultural pedagogy share many common traits. Hence, intercultural education is not only about appreciating cultural richness, but also about a critical understanding of knowledge; students must be taught to question the very origins of knowledge and power 
relations embedded in it (Apple, 1992). Moreover, intercultural education does more than show respect for minority identities; it investigates the nature and role of identity in the contemporary era (Beck \& Beck Gernsheim, 2002).

\section{Intercultural education in the critical pedagogy framework}

Based on these considerations, it can be concluded that intercultural education should be developed within the theoretical framework of critical pedagogy, which brings the normative aspect back into pedagogical methodology after the long prevalence of positivism. Value judgements are part of science, and according to Mollenhauer (1969) the cognitive interest of pedagogy is one of emancipation. This interest should lead the researchers in their choice of problems and in their judgement. The value of knowledge is judged considering whether it contributes to our recognition of injustice and »enslaving relations (Horkheimer, 1981). It is therefore impossible for intercultural education to be apolitical: the education of ethnic and cultural minorities cannot be understood and analysed separately from the issues of structural inequality in society and school.

Another justification for such placement lies is in the understanding of the function of school. Critical pedagogy postulates that school should prepare its pupils for life in a society marked by economic injustice, migrations, violence, sexual inequality, the destruction of the natural environment, with emphasis on the mobilisation for its improvement. Similarly, intercultural pedagogy insists that education should be designed so as to foster the equality of opportunities for cultural and ethnical minorities and to prepare all its participants for a life in the culturally diverse society, as well as for active participation in its construction.

The basic function of school, which is also the basis for its educational concept, is the preparation of pupils for coexistence with other - and different - people. It does not primarily focus on education in the sense of developing the personality and spirituality, but in the sense of preparing for social life (Medveš, 1991; Suchodolski, 1974). This means that education practices should be developed considering the values leading to a peaceful and tolerant coexistence of different people, not interfering with the pupil's culturally and socially conditioned essence.

\section{Integrative education policies and the concept of education}

As mentioned above, integrative policies encourage such integration of minority students into school and society which enables successful learning without requiring them to abandon their specific ethnic/linguistic/cultural identity. Students accept the multicultural nature of society, acknowledging the rights of different minorities and embracing the coexistence of cultures and ethnic groups as their central value. If a multicultural society strives for a peaceful and constructive coexistence of different people, it must acknowledge the need to adapt and change itself. Interculturality, says Cushner (1998, p. 353), means giving and taking; it transcends tolerance and accepts cooperation as the norm. 
Integrative school policies can be linked to the concept of the denationalised state, which protects the national identity but does not discriminate against others (Rizman, 1995). This is achieved by basing the functioning of public institutions on civic culture (Rex, 1999), which does not imply the disappearance of folk cultures, morality and religion, but assigns them a new role: primarily the role of binding individual communities internally and of enabling a successful socialisation of individuals, whereby their social identities are developed. They function as a sort of shelter from the world, where abstract moral principles apply and the individuals can be independent.

Civic culture is based on the values which are the present basis of democratic societies (equality of opportunities and rights, parliamentarism, tolerance, etc.) and originate in the European tradition of the Enlightenment. They have also influenced the contemporary concepts of institutional education, in which the search for philosophy-based universal values has been replaced by the idea of what we may call negotiated universal values. With this idea, we renounce the unproductive search for uncontroversial and superhistorical ideas and are satisfied with modern values as a kind of basis for a balanced coexistence on our planet. Of course we must remain clearly aware of their historical and cultural foundations and their discursive nature (Benhabib, 1995; Medveš, 1991). This change of view enables pedagogy and school to overcome the conceptual problems of postmodernity and accepts the legitimacy of "small stories" - of folk morality and culture. For intercultural education, this position is very important, since it entails a productive relationship between the necessary universality which legitimises education in a pluralistic public school (Medveš, 2000), but may destroy cultural differences, and the cultural specifics, which are therefore not excluded from schools. In practice, this means that school can respect and encourage those «different « cultural elements which do not oppose the democratic values of the Enlightenment, and can at the same time remain prepared to listen to the voice of the other.

\section{Equal opportunities and unequal treatment within inclusive school}

It is justified to say that the equality of opportunities can be singled out as the central goal for modern education in general. At least in the last 60 years, most national school systems, with the assistance of international bodies such as UNESCO and through different international associations such as those developed by the EU, underwent reforms to include this principle (Faure et al., 1972; Husen et al., 1992). The attention first focused on equal opportunities of access, but later moved to the equality of start and the principle of equal actual opportunities for success (Kodelja, 2002).

As demonstrated by the modern school history, all measures and investments into school to improve the equality of opportunities for all its participants, especially the disadvantaged groups, in the end produced larger benefits for the middle class which had had privileges before (Husen et al., 1992). This observation resulted in even more attention being paid to quality and excellence, and to the elite school population; but because of the important role of education in social stability and cohesion, many authors continue to emphasise the importance of the equality of opportunities as the central principle of 
school policies and education in general. This principle actually means the application of the classical justice rule (Rawls, in: Kodelja, 2002), which states that in a situation where several persons compete for a limited amount of goods, the equal should be treated the same and the unequal differently. Kodelja (Kodelja, 2002) adds that the principle of equal educational opportunities is linked to the equality of access and also with the principle of equal start. This means that the principle of equal opportunities indeed combines two heterogeneous concepts: "Equal access requires a form (rights, procedures, modalities) of access, and equal start material conditions; equal access prohibits discrimination, and equal start presupposes it" (Kodelja, 2002: 17). This on one hand means that positive discrimination should be introduced whenever it compensates for an existing inequality; on the other it means that it is legitimate to treat different people differently in school. In educational terms, teaching (objectives, contents and methods) must be differentiated, i.e. adapted to the peculiarities and needs of students in order to enable them to achieve equivalent results (Strmčnik, 1987). Since the disadvantaged social groups include cultural and ethnic minorities, these principles also apply to them.

The conclusion regarding the need for a different treatment of different people may be dangerous if we do not keep in mind its purpose, which is to use the different treatments to enable everybody to achieve equivalent results. Modern pedagogy believes that this can only be achieved in a comprehensive school with inclusive culture, otherwise it necessarily leads to a selective and segregation school system. Inclusive school has two key characteristics: (1) it assists every pupil to achieve a high standard of knowledge and development, presuming that this can be achieved without selection and segregation (Medveš, 2003), and (2), it creates such school climate and coexistence conditions that that individual, cultural and social differences are understood as an enrichment and a source of learning, so that differences turn into an actual equality (equality in difference). Inclusive school accepts individuals for what they are, not just as persons in a need of special treatment and adjustment.

Based on these considerations, I propose interculturality in education be defined as a pedagogical principle that guides the entire process of planning, implementing, and evaluating education at the systemic, curricular, school, and classroom levels to enable recognition and empowerment of all minority groups. It is a principle that supports: (1) the improvement of minority students' learning outcomes; (2) better recognition of their identities; and (3) a common education based on the values of participation, and cooperation.

\section{Measures supporting interculturality}

The implementation of the principle of interculturality is very demanding since it requires both a systemic restructuring and a considerable change of perspective from any number of actors. It also opens up new dilemmas and pitfalls, and must be therefore done with utmost caution. In order to be successful it should be introduced at several levels; if any is left out the chances of success decline precipitously; in general pedagogy we know that the effectiveness of education depends on the unity of educational action and that the more the educational factors are harmonized, the more likely is success. A perfect 
unity, however, remains impossible, since contradictions are to a certain extent always inherent to educational aims (Ermenc, 2005; 2015; Schmidt, 1975). To illuminate the complexity of intercultural education, let us first touch upon some of the possible measures at the systemic and curriculum levels - the number and nature of these measures cannot be exactly defined, since they depend on specificities of each educational, social, and political context:

The introduction of multi-perspective and cultural responsive curricula. Curricula from which the cases of ethnocentrism, stereotypes, and prejudice are eradicated; curricula that present history, geography, literature etc. from multiple perspectives and by inclusion of minority and neglected voices; and curricula that are flexible enough to enable teachers to respond to characteristics of their students. Curricula are accompanied by textbooks and other learning materials that follow the same ideas and include also texts, pictures, and names that give minority students an opportunity to identify with them.

1. The reconceptualization of mother-tongue learning and the promotion of multilingualism. The language of instruction is not the mother tongue of all students. If this is not recognized, an exclusivist discourse can evolve.

2. The organization of intensive and long-lasting second language learning, with simultaneous systematic support for early inclusion of immigrant students into mainstream education. Systemic support for teacher education that is based on interculturality in both the pre-certification and continuing professional education contexts.

3. Undertaking studies that investigate factors influencing low achievements of minority students and the evaluation of the success of intercultural interventions.

\section{How can teachers and other pedagogical workers support the principle of interculturality?}

Policymakers are responsible for the implementation of such system- and curriculum-related measures, which represent a base on which schools and teachers can build and without which their efforts are severely limited (Ermenc, 2007; 2015). In order to bring them to life however, a profound change of a school's ethos and pedagogical practices is required. Without teachers' readiness to change, interculturality will remain a purely paper tiger. Several scholars have proposed important measures that schools and teachers should take (Ermenc, 2010; Rutar, 2014; Vižintin, 2013):

1. Organizational measures: Intercultural education is not only about tackling the issues concerning newly arrived students from other countries. Schools, which welcome them on a regular basis, need to establish a sort of welcoming system including the provision of information booklets in several languages, interpreters (other students, local community members, etc.), intensive language courses, tutoring systems, and support mechanisms organized together with minority parents and minority societies.

2. Individualization and differentiation: A fundamental characteristic of every school that promotes an inclusive school ethos is its student-centeredness: individualized instruction and instruction in small groups is combined with whole-class instruction 
and common activities. Differentiation of students is however never long-lasting, and never functions as a means of segregation. The basic principle the school follows is to occasionally separate, but only for the purposes of bringing together in the end.

3. Intercultural and inclusive school ethos refers to giving voice to minority students: discussing ethnic relations in society, reflecting on the reasons for ethnic conflict, getting to know minorities' art, scientific achievements, etc. Inclusive schools also teach their students that heterogeneity is a normal state of humanity, that every person is in some way different from all others and that differences should be respected. Fundamentally, all people are the same in their human dignity and in their human needs.

4. Teachers' teamwork and teachers' responsibility: not only language teachers but all teachers are responsible both for the creation of an intercultural and inclusive school ethos and also for providing support to every single student.

5. Teachers' responsiveness and awareness of one's own prejudices: Teachers are only human and have prejudices and (positive or negative) stereotypes about their students. As teachers' prejudices and stereotypes may have a negative impact on their rapport with students and thus also on students' learning achievements (Wiggan, 2007), it is crucial that teachers become aware of them and do everything in their power to eradicate them. Teachers need to pose themselves questions such as: "Do I respond when I notice that a student is pushed aside or ignored? Do I respond when I notice that a student does not understand the lesson? Do I expect too little from this student (is he/ she capable of more)? Do I really respect and treat all my students equally? What will I do about it?"

\section{Conclusion}

Achieving such ambitious goals demands changes on the cognitive level, of course, but also on the affective and conative levels: pedagogical workers need not only to possess new information and knowledge (cognitive level), but also to be aware of their emotional interpretation of information and knowledge they have gained and understood (affective level). Moreover, they need to be willing to act on what they know (conative level).

Such complex aims cannot be achieved with one quick fix. Intercultural teacher education should begin at the undergraduate level, when prospective pedagogical workers gain the basic subject, pedagogical and psychological knowledge and insight. At that level, the focus can mostly be on cognitive levels, on "knowing what". Later on, intercultural teacher education should become a part of wider professional teacher development, involving the attendance at seminars and workshops, where more emphasis is usually given to the improvement of teachers' expertise and where more issues related to affective and conative levels begin to be raised. To be most successful, however, the affective and conative levels can be influenced at the school level by setting up a collaborative and externally supported professional development model. Such a model may include teachers' teamwork, formative peer observation, and cooperation in different projects with external experts and researchers. 


\section{References}

Apple, M. W. (1992). Šola, učitelj in oblast. Ljubljana: Znanstveno in publicistično središče.

Banks,J.A.(2009).Multicultural Education:Dimensions and Paradigms.In J.A.Banks(Ed.), The Routledge International Companion to Multicultural Education (pp. 9-32). New York: Routledge.

Beck, U. \& Beck Gernsheim, E. (2002). Individualisation: Institutionalized Individualism and its Social and Political Consequences. London: SAGE publishing.

Benhabib, S. (1995).Communicative Ethics and the Claims of Gender, Community and Postmodernism. In D. Tallack (Ed.), Critical Theory. A Reader. (pp.401-416). New York: Harvester Wheatsheaf.

Cushner, K. (1998). Intercultural Education from an International Perspective: Commonalities and Future Prospects. In K. Cushner (Ed.). International Perspectives on Intercultural Education. (pp. 353-370). New Yersey and London: Lawrence Erlbaum Associates Publishers.

Diehm, I. \& Radtke, F. O. (1999). Erziehung und Migration. Eine Einführung. Stuttgart, Berlin and Köln: W. Kohlhammer.

Ermenc, K. (2005). Limits of the Effectiveness of Intercultural Education and the Conceptualisation of School Knowledge. Intercultural Education, Vol. 16, No. 1, 41-55.

Ermenc, S. K. (2007). Is Education for the Coexistence of Different Cultures only Possible as a Subversive Activity of the Teacher? In S. Devetak (Ed.), The Success Story with the Aftertaste of Bitterness - Discrimination in Slovenia (pp. 66-74). Maribor: ISCOMET - Institute for Ethnic and Regional Studies.

Ermenc, S. K. (2010). Med posebnimi pravicami in načelom interkulturnosti. Sodobna pedagogikaJournal of Contemporary Educational Studies, Vol. 61, No. 2, 268-279.

Ermenc, S. K. (2015). Educating Teachers for Intercultural Education. In N. Popov, C. C. Wolhuter \& K. S. Ermenc (Eds.), Quality, Social Justice and Accountability in Education Worldwide: BCES Conference Books, Vol. 13, no. 1 (pp. 108-114). Sofia: Bulgarian Comparative Education Society.

Faas, D. (2008). From Foreigner Pedagogy to Intercultural Education: An Analysis of the German Responses to Diversity and its Impacts on Schools and Students, European Educational Research Journal, Vol. 7, No. 1, 108-123.

Faure, E., Herrera, F., Kaddoura, A. B., Lopes, H., Petrovsky, A. V., Rahnema, M. \& Wardet, F. Ch. (1972). Learning To Be. The World of Education Today and Tomorrow. Paris: UNESCO.

Grant, C. A. \& Portera, A. (Eds.) (2011). Intercultural and Multicultural Education: Enhancing Global Interconnectedness. New York: Routledge.

Horkheimer, M. (1981). Kritična in tradicionalna teorija. In S. Žižek (ur.), Kritična teorija družbe (pp. 29-81). Ljubljana: Mladinska knjiga.

Husen, T., Tuijnmann, A. \& Halls, W. D. (Eds.) (1992). Schooling in Modern European Society. A Report of the Academia Europaea. Oxford: Pergamon Press.

Kodelja, Z. (2002). Enakost in svoboda: temeljni vrednoti demokracije in šole. Sodobna pedagogikaJournal of Contemporary Educational Studies, Vol. 53, No. 5, 20-23.

McCarthy, C. (1995). Multicultural Policy Discourses on Racial Inequality in American Education. In R. Ng , P. Staton \& J. Scane (Eds.). Anti-Racism, Feminism, and Critical Approaches to Education. (pp. 22-48). London: Bergin \& Garvey. 
Medveš, Z. (1991). Pedagoška etika in koncept vzgoje. Sodobna pedagogika - Journal of Contemporary Educational Studies, Vol. 42, No. 3-4, 110-117.

Medveš, Z. (2000). Legitimnost vzgoje v javni šoli. Sodobna pedagogika - Journal of Contemporary Educational Studies, Vol. 51, No. 1, 186-177.

Medveš, Z. (2003). Šola zate in zame. Posebna izdaja: Integracija/inkluzija v vrtiću, osnovni in srednji šoli. Sodobna pedagogika - Journal of Contemporary Educational Studies, Vol. 54, No. 1, 84-103.

Mollenhauer, K. (1969). Erziehung und Emanzipation - Polemische Skizzen. Muenchen: Juventa Verlag.

Rex, J. (1999). The Concept of a Multicultural Society. In M. Guibernau \& J. Rex (Eds.), The Ethnicity Reader: Nationalism, Multiculturalism and Migration (pp. 205-219). Cambridge: The Polity Press.

Rizman, R. (1995). Nacionalna država, nacionalne manjšine in združena Evropa. In: D. Štrajn (ur.), Meje demokracije (str. 111-131). Ljubljana: Liberalna akademija, društvo za proučevanje politične demokracije in liberalizma.

Rutar, S. (2014). Multilingual Learning and Teaching as a Principle of Inclusive Practice. Sodobna pedagogika - Journal of Contemporary Educational Studies, Vol. 65, No. 1, 10-25.

Schmidt, V. (1975). Pedagoška metodologija. U L. Krneta, N. Potkonjak, V. Schmidt i P. Šimleša (ur.), Pedagogika I. (str. 121-187). Ljubljana: Državna založba Slovenije.

Sleeter, C. E. \& Grant, C. A. (1987). An Analysis of Multicultural Education in the United States. Harvard Educational Review, Vol. 57, No. 4, 421-445.

Sleeter, C. E. \& Grant, C. A. (2006). Making Choices for Multicultural Education: Five Approaches fo Race, Class, and Gender (5th ed.). New Jersey: Wiley.

Strmčnik, F. (1987). Sodobna šola v luči učne diferenciacije in individualizacije. Ljubljana: Zveza organizacij za tehnično kulturo Slovenije.

Suchodolski, B. (1974). Tri pedagogije. Beograd: Novinsko izdavačko preduzeće Duga.

Troyna, B. (1992). Can You See the Join? A Historical Analysis of Multicultural and Antiracist Education Policies. In D. Gill, B. Mayor \& M. Blair (Eds.), Racism and Education. Structures and Strategies (pp. 63-91). London: SAGE publishing.

Vižintin, M. A. (2013). Vključevanje otrok priseljencev prve generacije in medkulturni dialog v slovenski osnovni šoli (doktorska disertacija). Ljubljana: Filozofska fakulteta, Univerza v Ljubljani.

Wiggan, G. (2007). Race, School Achievement, and Educational Inequality: Toward a Student-Based Inquiry Perspective. Review of Educational Research, Vol. 77, No.3, 310-333.

Young, J. (1995). Multicultural and Anti-Racist Education: A Comparison of Canadian and British Experiences in the 1970s and 1980s. In R. Ng, P. Staton \& J. Scane (Eds.), Anti-racism, Feminism, and Critical Approaches to Education (pp. 45-63). Westport: Greenwood Publishing Group. 


\title{
ИНТЕРКУЛТУРАЛНЕ ДИМЕНЗИЈЕ ОБРАЗОВАҢА
}

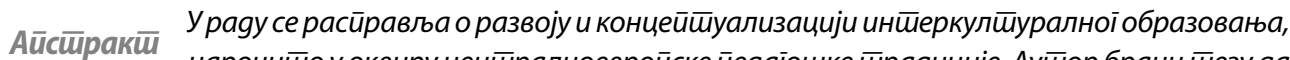

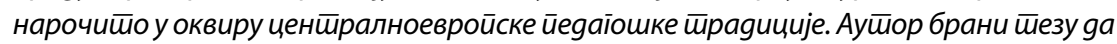

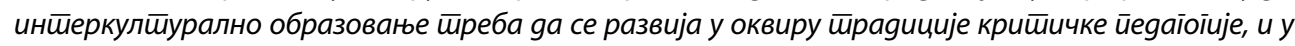

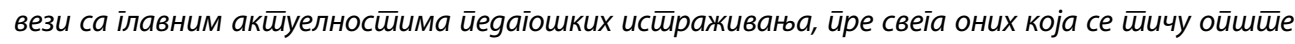

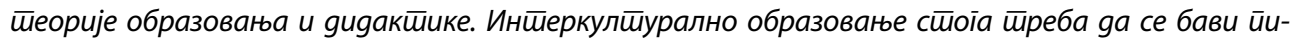

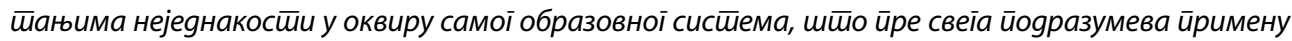

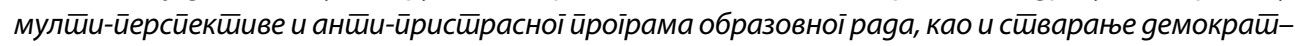

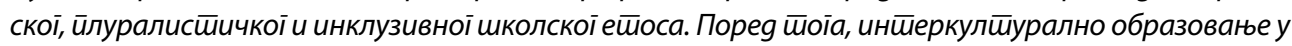
раgу није gефинисано као ӣосебна йеgаїошка gисцийлина, већ као йеgаїошки йринций на којем

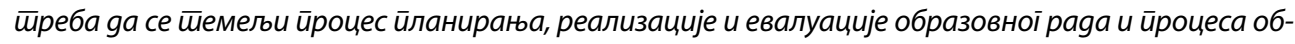
разовања на нивоу школскої сисиета, школе и учиониче, како би се омоїућило иррейознавање и оснаживање свих манинских іруйа. У закључном gелу раgа gаје се осврй на йеgаїошке мере за

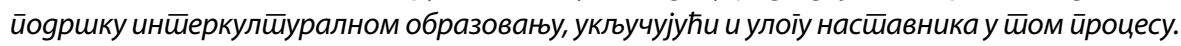

Кључне речи: иншееркулшиурално образовање, мулишикулйурално образовање, образовање насйавника, крийичка ӣegaі̄oīuja.

\section{МЕЖКУЛЬТУРНЫЕ АСПЕКТЫ ОБРАЗОВАНИЯ}

Резюме В статье рассматривается развитие и концептуализация межкультурного обраРезюме зования вообще и, в частности, чентрально-европейской педагогической традичии. Автор считает, что межкультурное образование должно развиваться в рамках традичии критической педагогики, учитывая при этом основные результаты современных педагогических исследований, в первую очередь, в области общей теории образования и дидактики. Межкультурное образование должно решать проблемы неравенства внутри самой системы образования, что, в первую очередь, подразумевает использование мультиперспективных и непристрастных программ образовательной работы, а также формирование демократического, плюралистического и инклюзивного школьного этоса. Кроме того, межкультурное образование в работе определяется не как особая педагогическая дисциплина, а как педагогический принцип, который должен ноходиться в основе планирования, реализации и эвальвации образовательной работы и прочесса обучения на уровне школьной системы, школы и класса. Таким образом обеспечивается идентификация, расширение прав и возможностей всех групп меньшинств. В заключительной части статьи дается обзор педагогических мер по поддержке межкультурному образованию и обсуждается роль учителя в этом процессе.

Ключевые слова: межкультурное образование, мультикультурноеобразование, образование преподавателей, критическая педагогика. 